\title{
Management of Storage Diseases of Onion by Using Different Fungicides and Antibiotics
}

\author{
A.S. Futane ${ }^{1 *}$, B.P. Dandnaik ${ }^{2}$, S.S. Salunkhe ${ }^{1}$, P.P. Jadhav ${ }^{1}$ and S.J. Magar ${ }^{2}$ \\ ${ }^{1}$ Department of Plant Pathology, College of Agriculture, Latur, India \\ ${ }^{2}$ Department of Plant Pathology, College of A griculture, Osmanabad VNMKV, \\ Parbhani, India
}

\begin{tabular}{|l|}
\hline K e y w o r d s \\
$\begin{array}{l}\text { Fungicides, Bioagents, } \\
\text { A. niger and Fusarium } \\
\text { oxysporum f.sp. cepae } \\
\text { culture }\end{array}$ \\
\hline Article Info \\
\hline $\begin{array}{l}\text { Accepted: } \\
\text { 10 January } 2018 \\
\text { Available Online: } \\
\text { 10 February } 2018\end{array}$ \\
\hline
\end{tabular}

\section{A B S T R A C T}

Black mold and Fusarium base rot of onion is caused by Aspergillus niger and Fusarium oxysporum f.sp.cepae are the most destructive diseases of onion in storage causing accountable losses of about 80 per cent and more than 50 per cent respectively. The fungicides, evaluated in vitro were found fungistatic/antifungal against both pathogen. In A. niger the most effective fungicides with significantly highest mycelial growth inhibition were SAFF (94.55 per cent), carbendazim (92.22 per cent) and mancozeb (90.98 per cent). The bioagents viz., T. viride (85.61 per cent) and T.harzinum (82.19 per cent) were found potential antagonists against A.niger. In Fusarium oxysporum f.sp.cepae fungicides viz., hexaconazole, SAFF, mancozeb and carbendazim were found most effective with significantly highest mycelial growth inhibition of 91.73 per cent, 91.39 per cent, 90.82 per cent and 88.42 per cent respectively. The bioagents viz., $T$. viride (88.1 per cent) and T. harzianum (81.55 per cent) recorded significantly highest mycelial growth inhibition.

\section{Introduction}

Onion (Allium cepa L.), is a member of class Liliaceae and family Alliaceae, widely distributed and grown in tropical, sub-tropical and temperate climatic zones (Fritsch and Friesen, 2002). It is biennial crop (Bohanec et $a l ., 2003)$, and in India it is grown twice (Rabi and Kharif) in a year (NHRDF, 2009) The name " wild onion', is applied to a number of Allium species but A.cepa is exclusively known from cultivation and its wild original form is not known. The onion is most frequently a biennial or a perennial plant, but is usually treated as an annual and harvested in its first growing season.

Onion rightly called as "Queen of kitchen" is one of the oldest known and an important vegetable crop grown in India Onion is supposed to have its origin in the Middle East Asian Countries and introduced in India from 
Palestine. It belongs to family Alliaceae, and genus Allium with about 300 species. Onion is grown in three season i.e. Kharif, Rabi, and summer. In Kharif season, during May-June seeds are sown and transplanted during JulyAug months and onion become ready for harvesting during Oct-Nov month.

The post - harvest losses, viz. sprouting, rotting, and physiological loss in weight pose a great problem. It is reported that annual storage losses were over 40 per cent (Bhagachandani et al., 1980) and between 4060 per cent (Maini et al., 1984) in India. The rabi crop produce having more ability in storage and used for domestic, export and seed bulbs purposes form June to November.

Losses of onion during storage are considerable mainly due to sprouting and contamination by several microorganisms. Nearly $40 \%$ of the production is lost during post-harvest handling and sprouting. Microbial spoilage alone contributes approximately $15-20 \%$ of the total loss (Pantastico and Bantista, 1976; Bhagchandani et al., 1980). Earlier, (Quadri et al., 1982) stated that the spoilage caused by Aspergillus niger was as high as $80 \%$.

\section{Materials and Methods}

\section{Experimental site}

All the experiments (In vitro) were conducted at the Department of Plant Pathology, College of Agriculture, Latur.

\section{Collection of disease samples}

Onion bulbs showing symptoms of rot, black, brown and discolouration were randomly collected in the bags from the various markets and fields in the Osmanabad and Latur district. These collected bulbs were brought to the Plant Pathology, Laboratory, College of
Agriculture, Latur and subjected for further studies.

\section{Culture media}

Potato dextrose agar (PDA), the common laboratory culture medium was used as basal medium for isolation, purification, multiplication and maintenance of the pure culture of diseases.

\section{Chemicals}

Standard chemicals, reagents, fungicides, culture media etc. required for the experimentation were obtained from the department of Plant Pathology, college of Agriculture, Latur.

\section{Glass-wares}

The common glass-wares (Borosil and corning make) viz., Petri dishes, test tubes, conical flasks, volumetric flasks, measuring cyclinder, glass rods, beakers, funnel, pipettes etc. were obtained from the Department of Plant Pathology, College of Agriculture, Latur.

\section{Equipments}

The laboratory equipments viz., Autoclave, Hot air oven, Laminar-airflow Cabinet, BOD incubator, Refrigerator, Binocular Research Microscope, Electronic balance, $\mathrm{pH}$ meter, Mixer-cum-grinder etc. available at the Department of Plant Pathology, College of Agriculture, Latur were utilized, as and when required.

\section{Miscellaneous}

Inoculation needle, forceps, blotter papers, paper bags, polythene bags, spirit lamp, mercuric chloride, labels, scales, etc. available at the Department of Plant Pathology were used. 


\section{Fungicides}

The following ten systemic and non-systemic fungicides were used for in in vitro experiments conducted during present studies.

\section{Antibiotics}

Streptocycline and plantomycin these two antibiotics are used for the in vitro study.

\section{Isolation}

Naturally infected onion bulbs showing typical symptoms of diseases were collected from the markets and brought to the laboratory. The infected bulbs were stripped of their outer dry scales and small pieces of the infected onion bulbs were removed with a sterile knife and surface sterilized with $0.1 \%$ aqueous solution of mercuric chloride $\left(\mathrm{HgCl}_{2}\right)$ for two minutes and then washed by giving three changes with sterile distilled water to remove traces of mercuric chloride. The surface sterilized diseased scales were then inoculated on the solidified and cooled PDA (Potato Dextrose Agar) medium in $90 \mathrm{~mm}$ diameter sterilized Petri plates under aseptic conditions of Laminar-air-flow cabinet (make: ACS, Bangalore). Inoculated plates were then incubated in BOD incubator (make: MAC, Delhi) at $27+-1^{0} \mathrm{C}$ temperature. After three to four days of incubation, the well-developed mycelial growth, free from any contaminant was obtained. The developing fungal colonies were sub-cultured on fresh PDA plates to obtain pure culture.

\section{Identification}

The fungal isolates were identified, based on their cultural and morphological characteristics including shapes of spores or conidia (Barnett and Hunter, 1998). The frequency of isolation of each fungal species was recorded.

\section{Disease management Strategies}

\section{In vitro evaluation of fungicides}

Efficacy of ten fungicides viz., Carbendazim (50 WP), Mancozeb (75 WP), SAAF (75WP), Benomyl (50 WP), Hexaconazole (5 EC), Tebuconazole (25.9 EC), Copper oxychloride (50 WP), Difenconazole (25 EC), Topsin (70 WP), Captan (50 WP), and two antibiotics viz. Streptocyclin and Plantomycin was tested in vitro against Aspergillus niger and Fusarium oxysporum f.sp.cepae applying poisoned food technique (Nene and Thapliyal, 1984). The requisite quantity of each fungicide and antibiotic based on active ingredient was calculated and mixed thoroughly with autoclaved and cooled $\left(40^{\circ} \mathrm{C}\right)$ Potato dextrose agar medium (PDA) in conical flasks to obtain desired concentrations. Untreated PDA medium without fungicide served as control. Fungicide amended PDA medium was then poured in Petri plates (90 $\mathrm{mm}$ dia.).

After solidification of the medium, all the plates were inoculated aseptically with $5 \mathrm{~mm}$ culture disc of the test fungus obtained from a week old culture of A. niger and Fusarium oxysporum f.sp.cepae. The disc was placed on PDA in the centre of the Petri plate and plates were incubated at $27+1{ }^{\circ} \mathrm{C}$ in inverted position. Suitable numbers of replication were maintained for each treatment. When medium in the untreated control plates was fully covered with mycelial growth of the test fungus, radial mycelial growth was measured in all the treatment plates. The diameter of the colony was measured in two directions and average was recorded. Per cent inhibition of mycelial growth in treated plates was calculated by applying the formula given by Vincent (1947).

Per cent inhibition $(I)=\frac{\text { C }-\mathrm{T}}{\mathrm{C}}$ 
Where,

$\mathrm{C}=$ Growth (mm) of test fungus in control plate,

$\mathrm{T}=$ Growth $(\mathrm{mm})$ of test fungus in treated plate.

\section{Experimental details}

Design: C.R.D.

Replication: Three

Treatment: 13

T1: Carbendazim (1000ppm)

T2: Mancozeb (2500 ppm)

T3: Benomyl (1000 ppm)

T4: Copper oxychloride (3000 ppm)

T5: Topsin (1000 ppm)

T6: Captan (2500 ppm)

T7: Hexaconazole (1000ppm)

T8: Tebuconacozole (1000 ppm)

T9: Difenconazole (1000 ppm)

T10: SAAF (2500 ppm)

T11: Streptocycline (500ppm)

T12: Plantomycin (500ppm)

T13: Control

Observations on radial mycelia growth/ colony diameter were recorded at $24 \mathrm{hrs}$ interval and continued till the untreated control plates were fully covered with mycelial growth of the test fungus.

Per cent mycelial growth inhibition of the test pathogen over untreated control was calculated by applying the formula given by Vincent (1947).

\section{Results and Discussion}

Present studies on the post-harvest and storage diseases of onion were undertaken during Rabi-2014 on the aspects of in vitro evaluation of fungicides. The results obtained on these aspects are presented in the following paragraphs.
In vitro evaluation of fungicides and antibiotics against $A$. niger

A total of ten fungicides viz., Carbendazim (50 WP), Mancozeb (75 WP), SAAF (75WP), Benomyl (50 WP), Hexaconazole (5 EC), Tebuconazole (25.9 EC), Copper oxychloride (50 WP), Difenconazole (25 EC), Topsin (70 WP), Captan (50 WP) and also two antibiotics Streptocycline $(0.5 \%)$ and Plantomycin $(0.5 \%)$ were evaluated in vitro against Aspergillus niger applying Poisoned Food Technique (Nene and Thapliyal, 1993), and using Potato dextrose agar (PDA) as basal medium. Effect of these fungicides and antibiotics on radial mycelia growth and inhibition of test pathogen were recorded. All the treatments were replicated thrice and a suitable untreated control (without fungicides) was also maintained.

\section{Radial mycelial growth}

Result revealed that all fungicides and antibiotics tested recorded a wide range of radial mycelial growth (colony diameter) of the test pathogens.

In Aspergillus niger the radial mycelial growth recorded with the fungicides tested ranged from $4.90 \mathrm{~mm}$ (mancozeb + carbendazim) to $22.56 \mathrm{~mm}$ (difenconazole). However, highest mean radial mycelial growth was recorded with difenconazole $(22.56 \mathrm{~mm})$, which was followed by tebuconazole $(13.52 \mathrm{~mm})$, hexaconazole $(12.89 \mathrm{~mm})$, captan $(9.22)$, topsin (9.00), copper oxychloride $(8.89 \mathrm{~mm})$, mancozeb $(8.11 \mathrm{~mm})$, benomyl $(8.73 \mathrm{~mm})$ and carbendazim (7.00). Significantly least mean radial mycelial growth was recorded with mancozeb+ carbendazim $(4.90 \mathrm{~mm})$ compared to maximum radial growth $(90.00 \mathrm{~mm})$ in untreated control plates. And in antibiotics all of two gives maximum radial growth i.e. Streptocycline $(72.99 \mathrm{~mm})$ and Plantomycin $(80.00 \mathrm{~mm})$. 


\section{Systemic fungicides}

\begin{tabular}{|l|c|c|c|c|}
\hline Sr. No. & Common name & Trade Name & Active Ingredient & Manufacture \\
\hline 1. & Carbendazim & Bavistin & $50 \mathrm{WP}$ & Sulphur Mills \\
\hline 2. & Benomyl & Benlate & $50 \mathrm{WP}$ & Corom \\
\hline 3. & Topsin & Topsin-M & $70 \mathrm{WP}$ & J.U.pest \\
\hline 4. & Tebuconazole & Folicure & $25.9 \mathrm{EC}$ & Bayer \\
\hline 5. & Difenaconazole & Score & $25 \mathrm{EC}$ & Syngenta \\
\hline 6. & Hexaconazole & Contaf & $5 \mathrm{EC}$ & Devidayal limt. \\
\hline
\end{tabular}

\section{Combine fungicides}

\begin{tabular}{|c|c|c|c|c|}
\hline Sr. No. & Common name & Trade Name & Active Ingredient & Manufacture \\
\hline 1 & $\begin{array}{c}\text { Mancozeb 63\%+ } \\
\text { Carbendazim } 12 \%\end{array}$ & SAFF & $75 \mathrm{WP}$ & $\begin{array}{c}\text { Devidayal } \\
\text { limited }\end{array}$ \\
\hline
\end{tabular}

Non systemic fungicides

\begin{tabular}{|l|l|l|l|l|}
\hline Sr. No. & Common name & Trade Name & Active Ingredient & Manufacture \\
\hline 1 & Mancozeb & Dithane M-45 & $75 \mathrm{WP}$ & INDOFI \\
\hline 2 & Captan & Captaf & $50 \mathrm{WP}$ & INDOFI \\
\hline 3 & COC & Blitox,Blue coper & $50 \mathrm{WP}$ & Syngenta \\
\hline
\end{tabular}

\section{Antibiotics}

\begin{tabular}{|c|c|c|}
\hline Sr. No. & Name & Manufacture \\
\hline 1 & Streptocycline & Hindusta Antibiotic Limited \\
\hline 2 & Plantomycin & Arise Agro Limited \\
\hline
\end{tabular}

In vitro effect of different fungicides on mycelial growth and inhibition of $A$. niger

\begin{tabular}{|l|c|c|c|c|}
\hline Tr. No & Treatments & Conc. $(\boldsymbol{\%})$ & Colony diameter $*(\mathbf{m m})$ & Per cent inhibition \\
\hline 1. & Carbendazim & 0.1 & 7.00 & $92.22(67.25)^{*}$ \\
\hline 2. & Mancozeb & 0.25 & 8.11 & $90.98(65.49)$ \\
\hline 3. & Benomyl & 0.1 & 8.73 & $90.29(64.56)$ \\
\hline 4. & Copper oxychloride & 0.3 & 8.89 & $90.12(64.31)$ \\
\hline 5. & Topsin & 0.1 & 9.00 & $89.99(64.17)$ \\
\hline 6. & Captan & 0.25 & 9.22 & $89.75(64.01)$ \\
\hline 7. & Hexaconazole & 0.1 & 12.89 & $85.67(59.42)$ \\
\hline 8. & Tebuconazole & 0.1 & 13.52 & $74.97(58.30)$ \\
\hline 9. & Difenconazole & 0.1 & 22.56 & $94.55(71.20)$ \\
\hline 10. & SAFF & 0.25 & 4.90 & $18.89(10.89)$ \\
\hline 1. & Streptocycline & 0.5 & 72.99 & $11.11(6.37)$ \\
\hline 12. & Plantomycin & 0.5 & 80.00 & 00.00 \\
\hline 13 & Control & & 90.00 & $\mathbf{1 . 7 0}$ \\
\hline & S.E. \pm & & $\mathbf{1 . 2 8}$ & $\mathbf{4 . 9 8}$ \\
\hline
\end{tabular}

*: Figures in parenthesis arc sin transformed values Mean of three replications 
In vitro effect of different fungicides on growth and inhibition of Fusarium oxysporum $f$. sp. cepae

\begin{tabular}{|l|c|c|c|c|}
\hline Tr. No & Treatments & Conc. $(\mathbf{\%})$ & Colony diameter *(mm) & Per cent inhibition \\
\hline 1. & Carbendazim & 0.1 & 10.42 & $88.42(62.30)^{*}$ \\
\hline 2. & Mancozeb & 0.25 & 8.26 & $90.82(65.36)$ \\
\hline 3. & Benomyl & 0.1 & 15.54 & $82.73(55.83)$ \\
\hline 4. & Copper oxychloride & 0.3 & 9.99 & $88.9(62.75)$ \\
\hline 5. & Topsin & 0.1 & 15.44 & $82.84(55.99)$ \\
\hline 6. & Captan & 0.25 & 16.43 & $81.74(54.84)$ \\
\hline 7. & Hexaconazole & 0.1 & 7.44 & $91.73(66.06)$ \\
\hline 8. & Tebuconazole & 0.1 & 20.23 & $77.52(50.83)$ \\
\hline 9. & Difenconazole & 0.1 & 13.19 & $85.34(58.65)$ \\
\hline 10. & SAFF & 0.25 & 7.74 & $12.39(66.56)$ \\
\hline 11. & Streptocycline & 0.5 & 78.84 & $12.28(7.05)$ \\
\hline 12. & Plantomycin & 0.5 & 78.94 & 00.00 \\
\hline 13 & Control & & 90.00 & $\mathbf{1 . 2 1}$ \\
\hline & S.E. & & $\mathbf{0 . 9 5}$ & $\mathbf{3 . 1 5 3}$ \\
\hline
\end{tabular}

*: Figures in parenthesis arc sin transformed values Mean of three replications

In vitro efficacy of the fungicides on mycelial growth and inhibition of Aspergillus niger
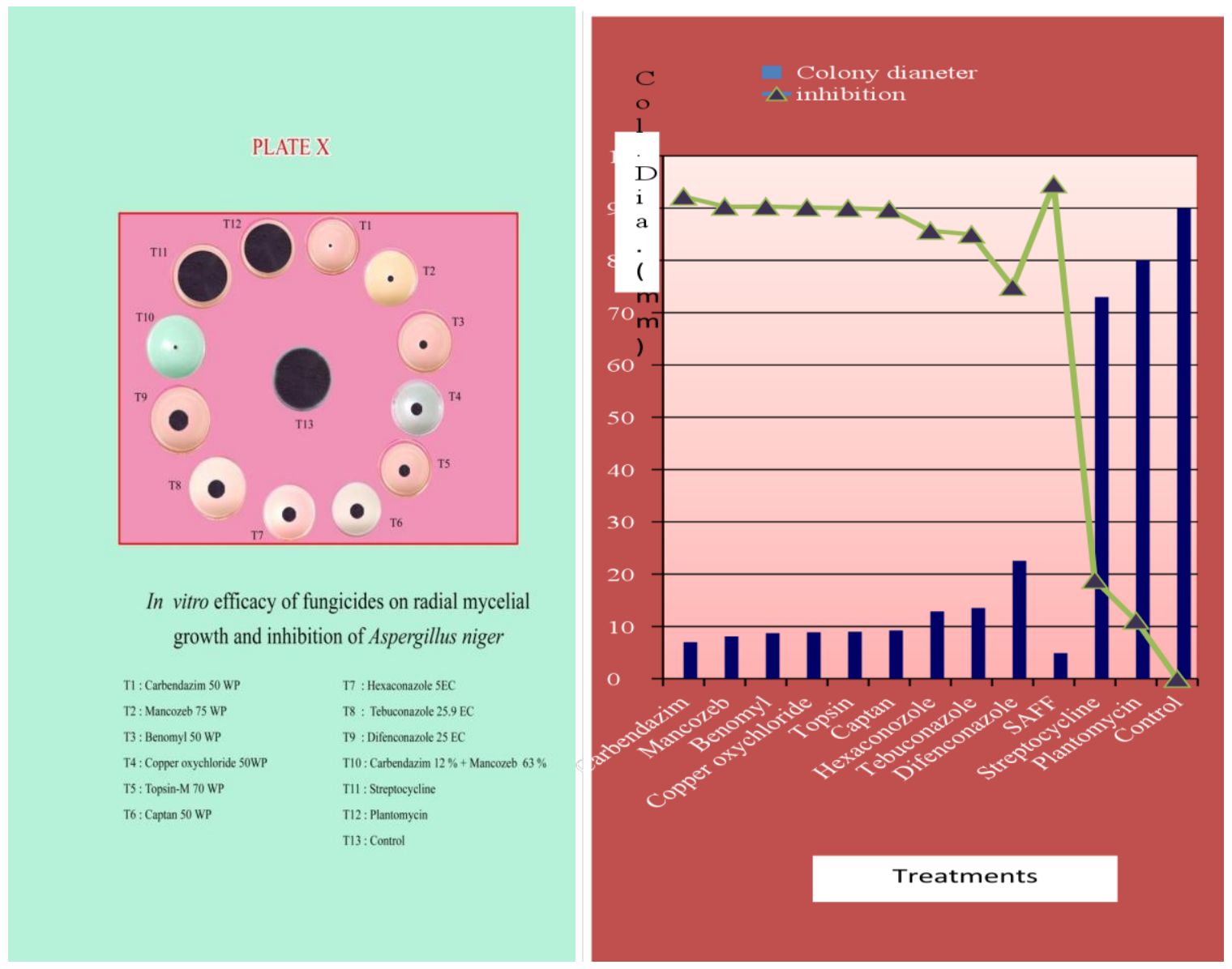


\section{In vitro efficacy of the fungicides on mycelial growth and inhibition of Fusarium oxysporum f.sp. cepae}

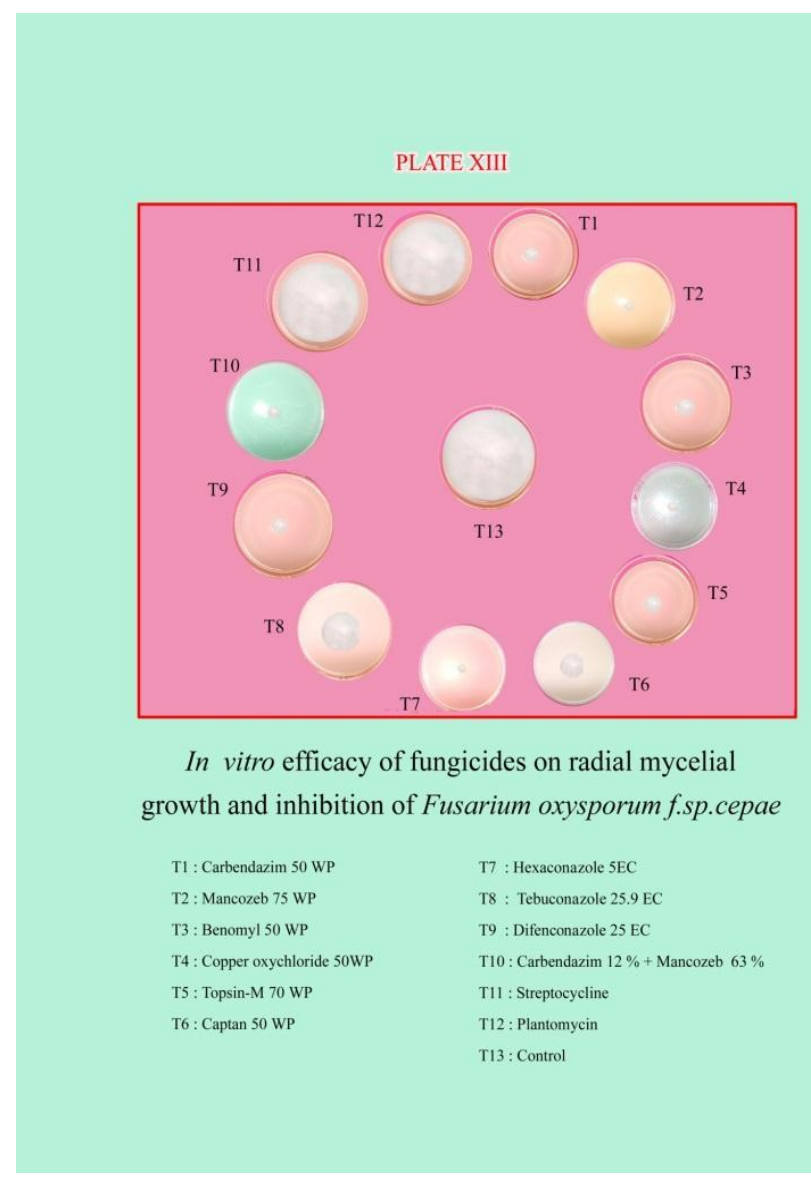

\section{Mycelial growth inhibition}

Results revealed that all the fungicides and antibiotics tested significantly inhibited mycelial growth of the test pathogen over untreated control $(00.00 \%)$.

In Aspergillus niger mycelial growth inhibition percentage recorded with all the fungicides tested ranged from $74.93 \%$ (Difenconazole) to $94.55 \%$ (Mancozeb+Carbendazim). However, mancozeb+carbendazim were found most fungistatic which recorded significantly highest mycelial growth inhibition of 94.55 per cent over untreated control $(00.00 \%)$. The second and third best fungicides found were carbendazim (92.22 \%) and mancozeb

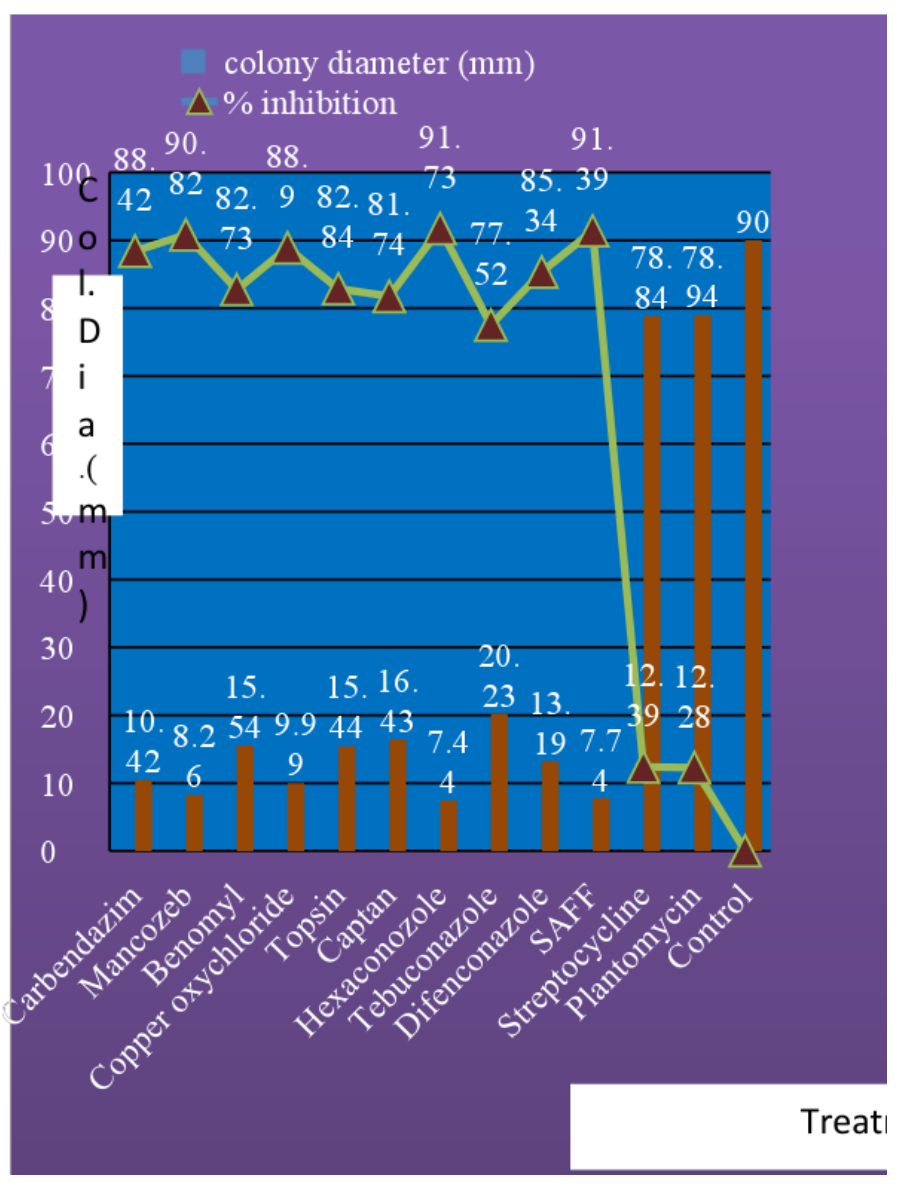

(90.98\%). This was followed by benomyl (90.29\%), copper oxychloride (90.12\%), topsin $(89.99 \%)$, captan $(89.75 \%)$, hexaconazole $(85.67 \%)$ tebuconazole $(84.97 \%)$ and difenconazole $(74.93 \%)$. And in antibiotics two gave minimum mycelial growth inhibition i.e. plantomycin (11.11\%) and streptocycline (18.89\%).

Thus the all the fungicides and antibiotics tested were found fungistatic/antifungal against $A$. niger and significantly inhibited its mycelial growth, over untreated control (00.00).

However, fungicides found most effective in the order of merit were SAFF, carbendazim, mancozeb, benomyl, copper oxychloride, 
topsin, captan, tebuconazole, hexaconazole and difenconazole. These results are similar to the findings of several workers (Suryawanshi and Deokar, 2001; Raju and Naik, 2006; Wani and Taskeen-Nisa, 2011 and Nandeesha et al., 2013).

\section{Fusarium oxysporum F.sp. cepae}

In vitro evaluation of fungicides and antibiotics

A total of ten fungicides viz., Carbendazim (50 WP), Mancozeb (75 WP), SAAF (75WP), Benomyl (50 WP), Hexaconazole (5 EC), Tebuconazole (25.9 EC), Copper oxychloride (50 WP), Difenconazole (25 EC), Topsin (70 WP), Captan (50 WP) and also two antibiotics Streptocycline $(0.5 \%)$ and Plantomycin $(0.5 \%)$ were evaluated in vitro against Fusarium oxysporum f.sp.cepae. applying Poisoned Food Technique (Nene and Thapliyal, 1993), and using Potato dextrose agar (PDA) as basal medium. Effect of these fungicides and antibiotics on radial mycelial growth and inhibition of test pathogen were recorded. All the treatments were replicated thrice and a suitable untreated control (without fungicides) was also maintained.

\section{Radial mycelial growth}

Result revealed that all fungicides and antibiotics tested recorded a wide range of radial mycelial growth (colony diameter) of the test pathogens.

In Fusarium oxysporum f.sp. cepae the radial mycelial growth recorded with the fungicides tested ranged from $7.44 \mathrm{~mm}$ (hexaconazole) to $20.23 \mathrm{~mm}$ (tebuconazole). However, highest mean radial mycelial growth was recorded with tebuconazole $(20.23 \mathrm{~mm})$, which was followed by captan $(16.43 \mathrm{~mm})$, benomyl (15.54), topsin (15.44mm), difenconazole (13.19mm), carbendazim (10.42 mm), copper oxychloride $(9.99 \mathrm{~mm})$, mancozeb $(8.26 \mathrm{~mm})$ and mancozeb+ carbendazim $(7.74 \mathrm{~mm})$. Significantly least mean radial mycelial growth was recorded with hexaconazole (7.44mm) compared to maximum mean radial growth $(90.00 \mathrm{~mm})$ in untreated control plates.

\section{Mycelial growth inhibition}

Results revealed that all the fungicides and antibiotics tested significantly inhibited mycelial growth of the test pathogen over untreated control (00.00\%). In Fusarium oxysporum f.sp.cepae mycelial growth inhibition percentage recorded with all the fungicides tested ranged from 77.52 (tebuconazole) to 91.73 (hexaconazole). However, hexaconazole found most fungistatic which recorded significantly highest mycelial growth inhibition of 91.73 per cent over untreated control (00.00). The second and third best fungicides found were mancozeb+carbendazim (91.39 \%) and mancozeb (90.82\%). This was followed copper oxychloride $(88.90 \%)$, carbendazim $(88.42 \%)$, difenocozole $(85.34 \%)$, topsin $(82.84 \%)$, benomyl $(82.73 \%)$, captan $(81.74 \%)$ and tebuconazole $(77.52 \%)$ and in antibiotics Streptocycline (12.39\%) and Plantomycin (12.28\%).

Thus all the fungicides and antibiotics tested were found fungistatic/antifungal against Fusarium oxysporum f.sp.cepae and significantly inhibited its mycelial growth over untreated control (00.00). However, fungicides found most effective in the order of merit were hexaconazole, SAFF, mancozeb, copper oxychloride, carbendazim, difenconazole, topsin, benomyl, captan and tebuconazole. These results are similar to the findings of several workers (Singh et al., 1997; Patel et al., 2005; Banyal et al., 2008; Barhate et al., 2011; Taskeen-Un-Nisa et al., 2011). 
All the 10 fungicides and 2 antibiotics tested in vitro were found fungistatic against Aspergillus niger and significantly inhibited its mycelial growth, over untreated control. However, mancozeb+carbendazim were found most fungistatic which recorded significantly highest mycelial growth inhibition of 94.55 per cent over untreated control $(00.00 \%)$. The second and third best fungicides found were carbendazim $(92.22 \%)$ and mancozeb (90.98\%). This was followed by benomyl (90.29\%), copper oxychloride (90.12\%), topsin $(89.99 \%)$, captan $(89.75 \%)$, hexaconazole $(85.67 \%)$, tebuconazole $(84.97 \%)$ and difenconazole $(74.93 \%)$. In antibiotics two gave minimum mycelial growth inhibition i.e. plantomycin $(11.11 \%)$ and streptocycline (18.89\%).

In Fusarium oxysporum f.sp.cepae all the test fungicides significantly inhibited mycelial growth over untreated control. However, hexaconazole found most fungistatic which recorded significantly highest mycelial growth inhibition of 91.73 per cent over untreated control (00.00). The second and third best fungicides found were mancozeb+carbendazim (91.39 \%) and mancozeb (90.82\%). This was followed by copper oxychloride $(88.90 \%)$, carbendazim $(88.42 \%)$, difenconazole $(85.34 \%)$, topsin $(82.84 \%)$, benomyl $(82.73 \%)$, captan $(81.74 \%)$ and tebuconazole $(77.52 \%)$. And in antibiotics Streptocycline (12.39\%) and Plantomycin (12.28\%) was least effective.

Thus from the results obtained on various aspects during investigation on postharvest and storage diseases of onion, following conclusions are being drawn.

All the test fungicides, evaluated in vitro found fungistatic / antifungal to both the pathogens (A.niger and Fusarium oxysporum f.sp. cepae). However, fungicides viz., SAFF, carbendazim, mancozeb copper oxychloride and benomyl were most effective against A.niger, whereas the fungicide viz., hexaconazole, SAFF, mancozeb and carbendazim were most effective against Fusarium oxysporum f.sp. cepae.

\section{References}

Banyal, D.K., Mankotia, V. and Sugha, S.K. (2008). Integrated management of collar rot caused by Sclerotium rolfsii. Journal of Mycology and Plant Pathology, 38(2): 165-16

Barhate, B.G., Bhore, A.D. and Raghuwanshi, K.S., (2011). Evaluation of fungicides and bioagents against Fusarium culmorum causing basal rot of garlic. J.Pl.Dis.Sci. 6(2):206-207

Bhagchandani, A., Netrapal, P.M., Narendra singh and Choudhuri, B., (1980). White onion for dehydration. Indian Hort. 24: 7-9.

Bohannec B., Jakse M., and Havey M.J., (2003). Genetic analyses of gynogenetic haploid production in onion. J.Am. Soc. Hort. Sci., 128, 571-574.

Fritsch M. and Friesen N., (2002). Evolution, domestication and taxonomy, in Allium crops Science: Recent Advances (H D Rabinowitch and L Currah, Eds), CABI Publishing, Wallingford, pp. 5-30.

Maini, S.B., Diwan, B. and Anand, J.C., (1984). Storage behaviour and drying characteristics of commercial cultivars of onion. J. of Food Science and Technology, 21(6):417

Nandeesha, B.S., Reddi Kumar M. and Eswara Reddy N.P., (2013). Evaluation of different fungicides and their compatibility with potential Trichoderma Spp. For the management of Aspergillus niger, incitant of collar rot of groundnut. Asian J. Biol.Life Sci.2(1): 59-63.

Nene, Y.L. and Thapliyal, P.N., (1984). Fungicides in plant disease control. $3^{\text {rd }}$ 
Edition, Oxford and IBH Publishing Co.PVT.LTD, New Delhi, India, 225 p.

NHRDF (2009), Area and production data, National Horticultural Research and Development Foundation, Available at: www.nhrdf.com.Accessed 14 April 2013.

Pantastico, B. and Bantista, O.K. (1976). Post-harvest handling of tropical vegetable crops. Hort Sci. 11: 122-124.

Patel, N.A., Dange S.R.S. and Patel, S.I. (2005). Efficacy of chemicals in controlling fruit rot of tomato caused by Alternaria tomato. Indian Journal of Agil.Res. 39:1.

Quadri, S.M.H., Srivastava, S.R, Bhonde, S.R., Pandey, U.B. and Bhagchandani, P.M., (1982). Fungicidal bioassay against some important pathogen of onion. Pesticides. 16(11):11-16.

Raju, K. and Naik, M.K. (2006). Effect of pre harvest spray of fungicides and botanicals on storage diseases of onion. Indian Phytopath. 59 (2): 133-141.

Singh, S.N., Yadav, B.P., Sinha, S.K., and Ojha, K.L. (1997). Efficacy of plant extracts in inhibition of radial growth of Colletotrichum capsici. Journal of Applied biology, 51: 180-183.

Suryavanshi, A.V. and Deokar, C.D., (2001). Effect of fungicides on growth and sporulation of fungal pathogen causing fruit rot of chilli. Madras Agric. J. 88:181-182.

Taskeen-Un-Nisa, Wani, A.H., Mohd Yaqub, Pala, S.A. and Mir, R.A., (2011). In vitro inhibitory effect of fungicides and botanicals on mycelial growth and spore germination of Fusarium oxysporum.J. of Biopesticides,4(1):53-56.

Wani, A.H. and Taskeen-Un-Nisa (2011). Management of black mold rot of onion. Mycopath 9(1):43-49.

\section{How to cite this article:}

Futane, A.S., B.P. Dandnaik, S.S. Salunkhe, P.P. Jadhav and Magar, S.J. 2018. Management of Storage Diseases of Onion by Using Different Fungicides and Antibiotics. Int.J.Curr.Microbiol.App.Sci. 7(02): 1149-1158. doi: https://doi.org/10.20546/ijcmas.2018.702.142 